\title{
Meningkatkan Hasil Belajar Mengoperasikan Peralatan Pengolahan Hasil Pertanian Dengan Metode Cooperative Learning Tipe Jigsaw
}

\author{
Dina Damayanti \\ SMKN 1 Cangkringan, Sleman, DIY \\ ditya,bd@gmail.com
}

\begin{abstract}
This study aims to improve student learning outcomes class XI TPHP 3 SMKN 1 Cangkringan by using the jigsaw type cooperative learning method. The subjects of this study were students of class XI TPHP 3 SMKN 1 Cangkringan which consisted of 29 students. Students were divided into several heterogeneous study groups consisting of 5-6 people using the pattern of the original group and the expert group. This research lasted two cycles, each of which consisted of two meetings. This research instrument is in the form of an assessment sheet. Primary data is revealed with value data and assessment criteria to record student learning outcomes in the action process and record the management of this research. Primary data were obtained by assessing the results of discussions, presentations, practices and written texts in the form of quizzes and formative tests. The data were analyzed using the reference grade for Vocational High Schools / Madrasab Aliyah Kejuruan. The results of student assessments showed an increase in student learning outcomes from cycle I to cycle II. Thus, after undergoing an action process in the form of a jigsaw cooperative learning, there was an increase in student learning outcomes.
\end{abstract}

Keywords: learning outcomes; jigsaw type cooperative learning method

\begin{abstract}
ABSTRAK
Penelitian ini bertujuan meningkatkan hasil belajar siswa kelas XI TPHP 3 SMKN 1 Cangkringan dengan metode cooperative learning tipe jigsaw. Subjek penelitian ini adalah siswa kelas XI TPHP 3 SMKN 1 Cangkringan yang terdiri dari 29 siswa Siswa dibagi dalam beberapa kelompok belajar yang heterogen yang beranggotakan 5-6 orang dengan menggunakan pola kelompok asal dan kelompok ahli. Penelitian ini berlangsung dua siklus masing-masing siklus terdiri dari dua pertemuan. Instrumen penelitian ini berupa lembar penilaian. Data primer diungkap dengan data nilai dan kriteria penilaian untuk mencatat hasil belajar siswa dalam proses tindakan dan mencatat tata laksana pengelolaan penelitian ini. Data primer diperoleh dengan menilai hasil diskusi, presentasi, praktik dan ters tertulis yang berupa kuis dan tes formatif. Data dianalisis dengan menggunakan acuan penilaian kelas untuk Sekolah Menengah Kejuruan/Madrasah Aliyah Kejuruan. Hasil penilaian siswa menunjukkan peningkatan hasil belajar siswa dari siklus I ke siklus II. Dengan demikian setelah menjalani proses tindakan berupa cooperative learning tipe jigsaw terjadi peningkatan hasil belajar siswa.
\end{abstract}

Kata Kunci: hasil belajar; cooperative learning tipe jigsaw

$$
\text { Submitted May 20, } 2021 \text { | Revised Jun 18, } 2021 \text { | Accepted Jun 25, } 2021
$$

\section{Pendahuluan}

Pembelajaran merupakan aspek terpenting dalam suatu jenjang pendidikan. Hal ini terkait dengan target kompetensi yang diharapkan dicapai atau dikuasai oleh peserta didik (Arjanggi, 2013). Di dalam proses pembelajaran terdapat beberapa aspek-aspek yang menunjang ketuntasan nilai pembelajaran. Aspek-aspek nilai yang dimaksud antara lain mencakup beberapa ranah yaitu ranah kognitif, ranah afektif dan ranah psikomotorik. Dalam penerapannya, keempat ranah tersebut merupakan suatu rangkaian yang terpisah namun saling berkaitan satu sama lain (Masluchah, 2013). Belajar Mengoperasikan Peralatan Pengolahan Hasil Pertanian pada dasarnya adalah merupakan belajar keterampilan yang bertujuan untuk memperoleh dan menguasai keterampilan, sehingga latihan-latihan yang terarah dan teratur sangat diperlukan. Sebagaimana yang penulis amati bahwa dalam kegiatan belajar mengajar Mengoperasikan Peralatan Pengolahan Hasil Pertanian sudah menerapkan pembelajaran praktik namun banyak siswa yang kesulitan dalam mempraktikkan konsep yang telah diterima, bagaimana cara yang tepat dan benar dalam 
mengoperasikan peralatan pengolahan. Kegiatan belajar mengajar tersebut biasanya hanya didominasi oleh siswa yang pandai sementara siswa yang kemampuannya rendah kurang berperan dalam mengerjakan tugas kelompok. Disamping itu juga siswa tidak dilatih untuk bekerja sama, berkomunikasi, dan menghargai pendapat orang lain. Akibat cara kerja kelompok seperti ini menyebabkan siswa yang kemampuannya kurang memperoleh hasil belajar Mengoperasikan Peralatan Pengolahan Hasil Pertanian yang tetap rendah dan adanya kesenjangan yang terlalu jauh antara hasil belajar siswa yang pandai dengan hasil belajar siswa yang kurang pandai.

Pembelajaran kooperatif tipe Jigsaw merupakan salah satu tipe strategi pembelajaran yang kooperatif dan fleksibel. Dalam pembelajaran tipe Jigsaw, siswa dibagi menjadi kelompok-kelompok yang anggotanya mempunyai karakteristik heterogen (Nurhadi, 2019; Megawati, et al, 2021; Hasanah, 2021). Masing-masing siswa bertanggung jawab untuk mempelajari topik yang ditugaskan dan mengajarkan pada anggota kelompoknya, sehingga mereka dapat saling berinteraksi dan saling bantu (Hertiavi, 2010). Jigsaw didesain selain untuk meningkatkan rasa tanggung jawab siswa secara mandiri juga dituntut saling ketergantungan yang positif (saling memberi tahu) terhadap teman sekelompoknya (Hartini, 2021). Selanjutnya di akhir pembelajaran, siswa diberi kuis secara individu yang mencakup topik materi yang telah dibahas. Kunci tipe Jigsaw ini adalah interdependensi setiap siswa terhadap anggota tim yang memberikan informasi yang diperlukan dengan tujuan agar dapat mengerjakan kuis dengan baik (Luvitasari, 2016).

Berdasarkan uraian di atas, dapat dikatakan bahwa rendahnya aktivitas, dan hasil belajar Mengoperasikan Peralatan Pengolahan Hasil Pertanian siswa dapat disebabkan oleh beberapa faktor antara lain: (1) Penyampaian materi Mengoperasikan Peralatan Pengolahan Hasil Pertanian oleh guru dengan metode praktik secara berkelompok membuat tidak semua siswa dapat melaksanakan praktik; (2) Praktik yang dilaksanakan secara berkelompok membuat beberapa siswa kurang bertanggung jawab terhadap pembelajarannya sendiri dan juga pembelajaran orang lain. Berdasarkan hal tersebut diatas bahwa untuk meningkatkan hasil belajar siswa terhadap materi pelajaran Mengoperasikan Peralatan Pengolahan Hasil Pertanian perlu adanya perbaikan dalam pembelajaran, yaitu strategi pembelajaran dengan menggunakan pendekatan keterampilan proses melalui metode Jigsaw. Berangkat dari kenyataan di atas, maka penulis berkeinginan untuk mengadakan penelitian tindakan kelas untuk mencapai harapan di atas.

\section{Metode Penelitian}

Penelitian ini menggunakan metode penelitian tindakan kelas karena penelitian yang dilakukan di kelas dengan tujuan memperbaiki/ meningkatkan mutu praktik pembelajaran (Arikunto, 2011). Desain penelitian ini menggunakan desain putaran spiral oleh Kemmis \& Mc Taggart. Adapun bagan alur PTK yang digunakan adalah sebagai berikut:

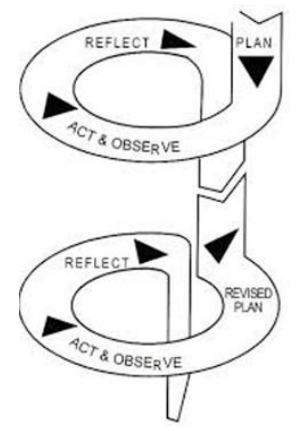

Gambar 1. Siklus Penelitian Tindakan Kelas

Sumber: (Kemmis dan Mc. Taggart, 1998: 11)

. Secara garis besar desain tersebut mempunyai beberapa tahapan yaitu: perencanaan (plan), pelaksanaan dan pengamatan (act \& observe), dan refleksi (reflect). 
Penelitian ini diimplementasikan di Sekolah Menengah Kejuruan Negeri 1 Cangkringan, Sleman dengan subjek siswa kelas kelas XI TPHP 3 semester 4 Tahun Pelajaran 2015/2016. Penelitian dilaksanakan selama lebih kurang 4 bulan sejak Januari sampai dengan Mei 2016 mulai tahap persiapan (penyusunan Silabus, LKS, persiapan alat dan bahan, uji coba praktikum, dan penyempurnaan LKS), sampai dengan tahap pelaksanaan (pembelajaran di sekolah) dan tahap pelaporan. Pada tahap pelaksanaan di kelas, materi pokok yang menjadi objek penelitian adalah materi Mengoperasikan Peralatan Pengolahan Hasil Pertanian.

Evaluasi terhadap keberhasilan tindakan dilakukan melalui penilaian proses atau prosedur dilaksanakannya praktik Mengoperasikan Peralatan Pengolahan Hasil Pertanian, yang juga dimaksudkan untuk mengukur tingkat pemahaman siswa terhadap konsep-konsep Mengoperasikan Peralatan Pengolahan Hasil Pertanian yang ada pada masing-masing pokok bahasan pada setiap siklusnya dan penilaian produk untuk mengukur keberhasilan pelaksaan Mengoperasikan Peralatan Pengolahan Hasil Pertanian. Data yang dikumpulkan merupakan data kuantitatif d, data kuantitatif diperoleh melalui penilaian selama melaksanakan pembelajaran Mengoperasikan Peralatan Pengolahan Hasil Pertanian.

\section{Hasil dan Pembahasan}

1. Siklus I

Pada siklus I siswa hadir semua dan mengikuti pembelajaran dengan tertib. Siswa aktif dalam pembelajaran Mengoperasikan Peralatan PHP tentang Mengidentifikasi fungsi dan prinsip kerja peralatan PHP dengan metode Jigsaw.

Guru melakukan pembelajaran sesuai rencana perbaikan pembelajaran yang telah dipersiapkan dengan model pembelajaran Cooperative Learning Tipe Jigsaw. Pada awal kegiatan guru memberi pertanyaan untuk mengetahui kemampuan siswa tentang Mengidentifikasi fungsi dan prinsip kerja peralatan PHP dan menyampaikan tujuan pembelajaran. Pada kegiatan inti guru bersama siswa membentuk kelompok kecil terdiri dari lima sampai dengan enam anggota dengan memperhatikan kemampuan, satu anak menjadi ketua kelompok. Guru membagi lembar kerja kepada tiap-tiap kelompok, ketua kelompok membagi tugas kepada para anggotanya. Guru membimbing siswa membentuk kelompok baru yang anggotanya dari masing-masing utusan kelompok. Setelah batas waktu yang diberikan untuk mengerjakan soal atau tugas selesai, masing-masing utusan kelompok kembali ke kelompok asal untuk mendiskusikan hasil temuannya. Masing-masing kelompok mempresentasikan hasil pekerjaan didepan kelas, guru memberi penilaian pada pertemuan pertama di akhir pembelajaran guru memberi soal kuis, sedang pada pertemuan ke dua guru memberi tes formatif.

Pada proses Pengamatan, peneliti mengamati jalannya proses pembelajaran beserta rekan sejawat guru dengan menggunakan lembar penilaian yang telah disiapkan. Rekan sejawat bertugas menilai jalannya proses belajar mengajar secara keseluruhan meliputi penilaian diskusi, praktik maupun presentasi.

Hasil belajar siswa pada siklus I dapat diketahui bahwa hasil rerata nilai siswa mencapai 71,23 dan prosentase nilai siswa yang $\geq 75$ sebanyak $06,89 \%$. Berarti pelaksanaan pembelajaran pada siklus I berjalan kurang baik sehingga hasil belum maksimal karena guru dan siswa belum berpengalaman sehingga sering terjadi kesalahfahaman.

2. Siklus II

Pada siklus II siswa juga hadir semua dan mengikuti pembelajaran sampai selesai. Keaktifan siswa dalam siklus ini meningkat.

Guru melakukan pembelajaran sesuai rencana perbaikan pembelajaran. Pada kegiatan awal guru bertanya kepada siswa untuk mengetahui kemampuan awal siswa tentang Mengoperasikan peralatan pengolahan dan menyampaikan tujuan pembelajaran. Melaksanakan pembelajaran yang telah dipersiapkan yaitu menyampaikan sub materi pokok dengan model pembelajaran Cooperative Learning 
Tipe Jigsaw. Guru bersama siswa membentuk lima kelompok kecil terdiri dari anggota dengan memperhatikan penyebaran tingkat kecerdasan berfikir. Guru membagi lembar kerja siswa kepada tiaptiap kelompok, ketua kelompok membagi tugas kepada para anggotanya. Guru membimbing siswa membentuk kelompok baru yang anggotanya dari masing-masing utusan kelompok, setelah batas waktu yang diberikan untuk mengerjakan soal atau tugas selesai, masing-masing utusan kelompok kembali ke kelompok asal untuk mendiskusikan hasil temuannya. Masing-masing kelompok mempresentasikan hasil pekerjaannya didepan kelas, guru memberikan penilaian. Pada pertemuan pertama di akhir pembelajaran, guru memberi soal kuis, sedang pada pertemuan ke dua guru memberi tes formatif. Proses Pengamatan Observer mengamati jalannya proses pembelajaran dengan menggunakan lembar observasi yang telah dipersiapkan.

Hasil belajar siswa pada siklus II tersebut dapat diketahui bahwa hasil rerata penilaian siswa mencapai 76,83 dan prosentase siswa yang memperoleh nilai $\geq 75$ sebanyak $82,75 \%$. Berarti pelaksanaan pembelajaran pada siklus II dapat mengalami peningkatan yang signifikasn. Ini dikarenakan antara siswa dan guru sudah memiliki pengalaman yang cukup menggunakan metode cooperative tipe jigsaw.

\section{Kesimpulan}

Dari hasil penelitian yang diperoleh, dapat disimpulkan bahwa penelitian ini menunjukkan pembelajaran dengan metode cooperative learning tipe jigsaw dapat meningkatkan hasil belajar siswa dalam Mengoperasikan Peralatan Pengolahan Hasil Pertanian.

\section{Daftar Pustaka}

Arikunto, S. (2011). Prosedur Penelitian Suatu Pendekatan Praktek. Jakarta. Rineka Cipta.

Arjanggi, R., \& Setiowati, E. A. (2013). Meningkatkan belajar berdasar regulasi diri melalui pembelajaran kooperatif tipe jigsaw. Makara Seri Sosial Humaniora, 17(1), 55-63.

Hasanah, Z. (2021). Model Pembelajaran Kooperatif Dalam Menumbuhkan Keaktifan Belajar Siswa. Irsyaduna: Jurnal Studi Kemahasiswaaan, 1(1), 1-13. Retrieved from https://jurnal.stituwjombang.ac.id/index.php/irsyaduna/article/view/236

Hartini, H. (2021). Upaya Meningkatkan Hasil Belajar Siswa Melalui Pembelajaran Kooperatif Teknik Jigsaw Pada Siswa Sekolah Menengah Pertama. Keluarga: Jurnal Ilmiah Pendidikan Kesejabteraan Keluarga, 7(1), 1-14.

Hertiavi, M. D., Langlang, H., \& Khanafiyah, S. (2010). Penerapan model pembelajaran kooperatif tipe jigsaw untuk peningkatan kemampuan pemecahan masalah siswa SMP. Jurnal pendidikan fisika Indonesia, 6(1).

Kemmis, Stephen \& Robin Mc Taggart. (1988). The Action Research Planner. Victoria: Deakin University.

Lie, A. (2008). Cooperative Learning. Mempraktikkan Cooperative Learning di Ruang-ruang Kelas. Jakarta : Gramedia Widiasarana Indonesia.

Luvitasari, A. (2016). Pengaruh Model Pembelajaran Tutor Sebaya Terhadap Hasil Belajar Teknologi Pengolahan Makanan Di Smk Negeri 1 Berastagi (Doctoral dissertation, UNIMED).

Masluchah, Y. (2013). Penerapan Model Pembelajaran Kooperatif Tipe Jigsaw untuk Meningkatkan Hasil Belajar IPS Siswa Kelas IV Sekolah Dasar. Jurnal Penelitian Pendidikan Guru Sekolah Dasar, 1(2), 1-10.

Megawati, R., Leksono, I. P., \& Harwanto, H. (2021). Implementasi Pembelajaran Kooperatif Tipe Jigsaw Terhadap Hasil Belajar Matematika Ditinjau Dari Tipe Kepribadian Siswa. Jurnal Education And Development, 9(1), 19-19.

Nurhadi, N. (2019). Penerapan Model Pembelajaran Cooperative Learning Tipe Jigsaw Untuk Meningkatkan Hasil Belajar Fisika Siswa Kelas XII IPA 3 SMA Negeri 3 Bengkalis. Journal of Natural Science and Integration, 2(1), 76-84. 
Purbokawotjo, R. Suganda, A. Gazali, dan D.H. Dequitjo (1990). Pengantar Paedagogik. Jakarta. Penerbit Ganeca.

Rohani H.M., Ahmad. (2004). Pengelolaan Pengajaran. Jakarta. PT. Rineka Cipta.

Sensialiana, L., Andriani, S., \& Sahmini, M. (2019). Pembelajaran Menulis Teks Drama Menggunakan Model Jigsaw. Parole (Jurnal Pendidikan Bahasa dan Sastra Indonesia), 2(5), 783-792.

Suparman, M. Atwi, (2001). Desain Instruksional. Pekerti Mengajar di Perguruan Tinggi. Jakarta: Universitas Terbuka.

Tritjahjo Danny Soesilo, (2015). Teori dan Pendekatan Belajar : Implemantasi dalam Pembelajaran. Yogyakarta. Penerbit Ombak. 